\title{
Motivations for smoking in hospitalized patients
}

\author{
(iD) Gustavo Freitas Grad ${ }^{1}$ \\ (D) Mariangela Pimentel Pincelli ${ }^{1}$ \\ (iD) Karolinny Moura' \\ (iD Cristiane Rocha ${ }^{1}$ \\ (iD) Ana Karoline Alves ${ }^{1}$ \\ Lucas Menezes Mercado Lobo' \\ (iD) Bruno Silva ${ }^{1}$ \\ (iD) Leila Steidle
}

1. University Hospital Polydoro Ernani de São Thiago, Federal University of Santa Catarina, Trindade, Florianópolis, Santa Catarina, Brasil

http://dx.doi.org/10.1590/1806-9282.65.5.603

\section{SUMMARY}

OBJECTIVE: To investigate the profile of motivations for smoking among inpatients at a hospital in southern Brazil.

METHODS: A survey study involving hospitalized smokers. The Modified Reasons for Smoking Scale (MRFSS) and its domains were analyzed according to gender and dependence degree.

RESULTS: The sample consisted of 85 adults (mean age 53 years), low schooling/family income, and well-adjusted in terms of gender (male $=52.9 \%$ ) and clinical (48\%) or surgical (47\%) specialty. Most were in Action as the motivational stage (68\%), with elevated smoking exposure (median = 39 years/packs) and dependence degree of nicotine (56.4\%). The highest domains of the MRFSS were: Smoking Pleasure (4.34 \pm 1.2), Relaxation/Tension Reduction (4.24 \pm 1.2$)$ and Dependence (3.8 \pm 1.4$)$. Significantly, women presented

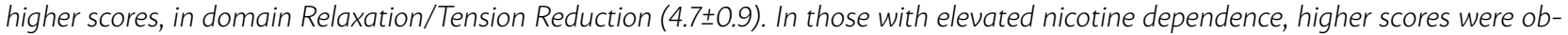
served in the Automatism/Habit and Stimulation domains.

CONCLUSIONS: Smoking Pleasure and Relaxation/Tension Reduction, especially in women and Automatism, in those more dependents, are factors that should be more highlighted in future strategies for smoking cessation in inpatients.

KEYWORDS: Tobacco Use Disorder. Motivation. Inpatients.

\section{INTRODUCTION}

Smoking, currently considered a pandemic by the World Health Organization (WHO), is the main risk factor for chronic non-communicable diseases such as cancer, cardiovascular and respiratory disorders. ${ }^{1,2}$ According to a report published in 2017 by the WHO, over seven million people lost their lives annually due to the direct consumption of tobacco and secondary exposure to its pollutants. ${ }^{1}$
In the national population, in 2003 , it is estimated that 178 thousand people aged 35 years or more died for reasons attributed to smoking. ${ }^{3}$ Still at a national level, over the last 20 years, thanks to anti-smoking measures, there was a decline of approximately 50\% in smoking prevalence in adults ${ }^{4}$. Pinto et al. ${ }^{5}$ highlighted the high burden of diseases attributable to tobacco use, in Brazil, in addition to the potential bene-

DATE OF SUBMISSION: 23-Apr-2018

DATE OF ACCEPTANCE: 08-May-2018

CORRESPONDING AUTHOR: Cristiane Rocha

Rua Maria Flora Pausewang, SN, Florianópolis, Santa Catarina, Brasil - 88040-900

Tel: 48-32347711

E-mail: cristiane.cinara@gmail.com 
fits of the price increases through taxes. In 1989, the proportion of smokers in national territory reached $32 \%{ }^{6}$ More recently, in 2016, the Surveillance System for Risk and Protective Factors for Chronic Diseases by Telephone Survey (VIGITEL) revealed that the prevalence of smoking had reached the total national average of $10.2 \%-12.7 \%$ among men and $8 \%$ among women ${ }^{7}$.

Why people smoke is an issue that has defied scholars for a long time. It is known that nicotine has psychoactive actions that result in dependence. However, the reasons that lead someone to smoke are multifaceted. Gately ${ }^{8}$ pointed out smoking as a characteristic of different civilizations throughout history with a social, religious and, curiously, medicinal role in them. Whereas Tomkins ${ }^{9}$, the pioneer in theories on the subject, stated that the four main reasons related to smoking are: habit, addiction, reduction of negative emotions, and reinforcement of positive emotions. Some studies have been directed toward identifying the reasons that lead an individual to cease smoking. ${ }^{10,11}$ However, to know the profile of motivations that contribute to smoking has been shown to potentially assist in the creation of individual and collective anti-smoking strategies. ${ }^{12-14}$

Several instruments have been developed to evaluate the influence of psychosocial aspects on smoking. ${ }^{12}$ Knowing these methods is the first step to draw qualified and comparative studies in this area. In 1966, the Scale of Reasons for Smoking emerged, divided into six categories: Handling, Pleasure, Automatism, Stimulation, Tension Reduction/Relaxation, and Addiction. However, it did not consider social smoking. ${ }^{9}$ Since it was validated and considered to be adequate regarding its psychometric properties, it became the first useful tool for elucidation of the subject $^{15}$. In the 1970s, Russel and collaborators ${ }^{16}$ ex- $^{-}$ panded the scale previously validated to add social issues related to smoking. Modified Scale of Reasons for Smoking (MRSS) was then born and originally used in France. ${ }^{17}$ The scale was translated into Portuguese, culturally adapted and validated for use in Brazil, which made it possible to use it in national studies on smoking. ${ }^{14,18}$ The scale has high internal consistency, stable factor structure, and temporal stability.

In recent years, specific groups of smokers have been well studied. Smoking in hospitalized patients is an example of a population often overlooked, as is withdrawal syndrome during the hospitalization pe- riod, which makes the need for a routine approach for this specific group of smokers relevant. Hospitalization allows for approaching and monitoring patients more intensely in order to transform this episode of "mandatory" tobacco interruption into a successful attempt of cessation. ${ }^{19,20}$ Furthermore, currently, non-smoking environments have become a reality increasingly close, and they include health care units.

Until now, studies that examine the various motivations involved in smoking in hospitalized patients are unknown. In this context, considering hospitalization a window of opportunity to recognize the motivational profile is of utmost importance to understand and plan specific strategies of treatment.

With the use of a standardized and validated scale, this study aims to investigate the profile of psychosocial motivations for smoking among hospitalized patients in the University Hospital Polydoro Ernani de São Thiago of the Federal University of Santa Catarina (HU-UFSC). In addition, the reasons in the scale were analyzed according to gender and degree of dependence.

\section{METHODS}

This is a survey type of study, with a convenience sample, conducted between May 2013 and June 2014. The population studied was composed of smokers, hospitalized in the medical or surgical clinics of HU-UFSC.

Patients included were smokers, aged over 18 years, hospitalized in the HU-UFSC for more than 48 hours, who were approached to participate in the smoking cessation program. We excluded patients who were non-smokers, unable to respond to the questionnaire, pregnant or lactating women, with abuse of psychoactive substances, in treatment for severe psychiatric and neurological disorders, as well as those who refused to participate in the research.

The survey instrument was a semi-structured questionnaire with sessions broken into closed questions that included data on identification, demographics, socioeconomic scenario, hospitalization, characteristics of the current and previous smoking habit of each patient, and body mass index (BMI). We considered patients current smokers those who declared smoking at least one cigarette every day for the past six months.

We investigated the behavioral characteristics 
related to smoking, including analysis of the motivational stage at the time of interview, classified using the scale by Prochaska and DiClemente ${ }^{21}$ on Precontemplation (no intention to quit smoking for the next 6 months), Contemplation (there is awareness of the problem and intention to quit smoking, but at an undefined date - ambivalence), Preparation (there is a desire to quit smoking in the near future, within approximately 1 month, and there have been actions towards this goal), Action (the individual stopped smoking), Maintenance (there is abstinence to smoking and surveillance to prevent relapse), and Relapse (the habit or previous behavior of tobacco consumption was resumed due to failure in the maintenance of abstinence or reduction in the number of cigarettes). Depending on the degree of dependence, we considered the Fagerström Test as: Very Low (0-2); Low (3-4); Moderate (5); High (6-7), and Very High (8-10)22.

We evaluated the patient's motivations for smoking using a previously validated instrument - the Modified Scale of Reasons for Smoking (MRSS). This scale has 21 questions, divided into seven motivational domains, namely: Dependency (questions $\mathrm{E}$ and S), Stimulation (questions $\mathrm{A}, \mathrm{H}$, and $\mathrm{O}$ ), Pleasure from Smoking (questions C and J), Handling (questions B and I), Social Smoking (questions G and N), Reduction of Tension/Relaxation (questions D, K, and R) e Automatism/Habit (questions F, M, and T). To each alternative, increasing gradual weights were attributed between 1 (never) and 5 (always), with the use of a Likert scale. The mean scores of each question of the domains were considered in the analysis. The scale was applied with the aid of the interviewers.

The collection and tabulation of data were carried out by trained researchers and collaborators.

The research was approved by the Human Research Ethics Committee at the Federal University of Santa Catarina (CEPSH-UFSC), under number 245.656. The interview with data collection was performed after a detailed explanation of the study, including their objectives, risks, and benefits to the patient, who previously signed the Informed Consent Form (ICF). The behavioral and pharmacological treatment, when necessary, was made available for all patients in the study, according to current guidelines. ${ }^{23}$

The data were entered and analyzed using the Statistical Package for Social Sciences (SPSS) software version 22. A descriptive analysis was performed on the data of identification, demographic, socioeco- nomic, hospitalization, and the characteristics of the current smoking habit and progress of each patient. The mean scores per MRSS domains were calculated using the arithmetic averages of responses, first per question and after, per domains. The continuous variables with normal distribution were expressed as mean and standard deviation, while non-normal continuous variables were presented in the form of median and interquartile range 25-75\% (IQR25-75). For purposes of comparison with the literature, the MRSS scores were expressed as mean and standard deviation regardless of the distribution. The categorical variables were expressed in terms of frequency and proportion. The differences between the reasons for smoking in relation to sex and degree of dependence were analyzed using the Mann-Whitney test. We considered $\mathrm{p}<0.05$ for statistical significance.

\section{RESULTS}

In the population studied of 85 smokers, we observed a median age of 53 years with a slight predominance of males $(52.9 \%)$, mostly married or co-dwelling (52.9\%), white (71.8\%), with a BMI within the normal range, mostly from the city of Florianópolis (43.5\%), natural of Santa Catarina (74.1\%). More than half were illiterate or with incomplete primary education (54.1\%) and with a median income of 1 minimum wage per capita (Table 1).

Among the patients included in the study, 41 were hospitalized in a surgical ward, 40 in a medical clinic, and 4 in the emergency. The median of hospital stay was 17 days (IQR25-75= 9 - 30). The main diagnoses of individuals were peripheral arterial occlusive disease (15.3\%) and neoplasia (14.2\%).

The participants in the sample began smoking early, with a median age of 15 years and a median of 37 years of exposure to tobacco. The median number of cigarettes smoked per day was 20 , and the nicotine load was 39 packs/year. The nicotine dependence, according to Fargeström test, showed that over half of the individuals presented a high or very high degree of dependence (56.4\%). In relation to the Prochaska and Diclemente motivational, the majority (68.2\%) of the smokers were in a state of action (Table 1).

In relation to the MRSS, the average of scores of the smokers and their standard deviations in the domains are presented in Table 2. After analyzing the results of the MRSS per domain, the most relevant were: Pleasure from Smoking $(4.34+1.2)$, Relax- 
TABLE 1. DATA ON DEMOGRAPHICS, SOCIOECONOMIC FACTORS, AND FACTORS RELATED TO THE SMOKING HABITS OF THE POPULATION STUDIED. (GRAD, 2014)

\begin{tabular}{|c|c|}
\hline Total & $(n=85)$ \\
\hline \multicolumn{2}{|l|}{ Age (years) } \\
\hline Mean (IQR 25 -75) & $53(45-61)$ \\
\hline \multicolumn{2}{|l|}{$\operatorname{Sex} n(\%)$} \\
\hline Male & $45(52.9)$ \\
\hline \multicolumn{2}{|l|}{ Marital status n (\%) } \\
\hline Married/co-dwelling & $45(52.9)$ \\
\hline Separated/divorced & $20(23.5)$ \\
\hline Single & $11(12.9)$ \\
\hline Widow(er) & $8(9.4)$ \\
\hline Others & $1(1.2)$ \\
\hline \multicolumn{2}{|l|}{ Ethnicity n (\%) } \\
\hline White & $61(71.8)$ \\
\hline Others & $24(28.2)$ \\
\hline \multicolumn{2}{|l|}{$\mathrm{BMI}\left(\mathrm{Kg} / \mathrm{m}^{2}\right)$} \\
\hline Mean $\left(I Q R_{25-75}\right)$ & $24.4(21.5-28.6)$ \\
\hline \multicolumn{2}{|l|}{ Per capita income (SM) } \\
\hline Mean $\left(I Q R_{25-75}\right)$ & $1.0(0.5-1.5)$ \\
\hline \multicolumn{2}{|c|}{ Formal education n (\%) } \\
\hline Illiterate/IPE & $46(54.1)$ \\
\hline CPE & $14(16.5)$ \\
\hline CSE & $19(22.4)$ \\
\hline Others & $6(7.1)$ \\
\hline \multicolumn{2}{|l|}{ SMOKING } \\
\hline \multicolumn{2}{|l|}{ Age that started } \\
\hline Mean $\left(I Q R_{25-75}\right)$ & $15(13-17)$ \\
\hline \multicolumn{2}{|l|}{ Exposure time } \\
\hline Mean $\left(I Q R R_{25-75}\right)$ & $37(28-46.5)$ \\
\hline \multicolumn{2}{|l|}{ Smoking load } \\
\hline Mean $\left(I Q R_{25-75}\right)$ & $39(24.2-74)$ \\
\hline \multicolumn{2}{|c|}{ Degree of dependence n (\%) } \\
\hline Very low & $6(7.1)$ \\
\hline Low & $16(18.8)$ \\
\hline Moderate & $15(17.6)$ \\
\hline High & $28(32.9)$ \\
\hline Very high & $20(23.5)$ \\
\hline \multicolumn{2}{|l|}{ Fagerström Test } \\
\hline Mean $\left(I Q R_{25-75}\right)$ & $6(4-7)$ \\
\hline \multicolumn{2}{|l|}{ Motivational stage } \\
\hline Contemplation & $17(20)$ \\
\hline Preparation & $9(10.6)$ \\
\hline Action & $58(68.2)$ \\
\hline Maintenance & $1(1.2)$ \\
\hline
\end{tabular}

ation/Reduction of Tension $(4.24+1.2)$, and Dependency $(3.80+1.4)$, followed by Automatism/Habit $(2.36+1.1)$, Handling(1.98 + 1.4), Social Smoking(1.81 $+1.2)$, and Stimulation $(1.63+1.0)$. The individual responses with the highest scores were: "I light a ciga- rette when I am angry about something," "smoking gives me pleasure and is relaxing" and "I think cigarettes are pleasant", with, respectively, the following means $4.42+1.3,4.38+1.2$, and $4.29+1.4$. "I smoke to keep me alert", mean $1.49+1.1$ and "I smoke cigarettes to cheer myself up”, mean $1.59+1.1$, were less common reasons for smoking (Figure 1).

We found that the domain with the highest score among men was Pleasure from Smoking. Among women, with statistical relevance, it was Relaxation/ Reduction of Tension (Table 2).

As for the degree of dependence, more than half (56.4\%) of the patients presented a high to very high degree. These, when compared to those with less dependence, presented, with relevance, higher scores in the domains of Automatism/Habit $(2.5+1.2) \times(1.92$ $+0.9), p=0.04$ and Stimulation $(1.77+1.1) \times(1.3+0.4)$, $\mathrm{p}<0.04$. Those with high dependency cannot be differentiated from those with less dependence in the domains with higher scores: Pleasure from Smoking $(4.45+1.1) \times(4.02+1.5), \mathrm{p}=0.28$ and Relaxation $(4.40$ $+1.1) \times(3.77+1.5), \mathrm{p}=0.06$.

No significant correlation $(r>0.5)$ was found between the domains and independent variables tested.

\section{DISCUSSION}

Through the use of a instrument validated for the Brazilian population, this study investigated the profile of psychosocial motivations for smoking in 85 patients hospitalized in a university hospital in southern Brazil. Additionally, we studied the MRSS domains in function of sex and degree of dependence and their possible correlations. The sample was composed of adults, white, with low formal education/ family income and balanced regarding the distribution per sex and clinical and surgical specialty. The majority was in the motivational stage of Action, with high levels of nicotine load and degree of nicotine dependence. The results showed that the MRSS areas with higher scores were Pleasure from Smoking, Relaxation/Reduction of Tension, and Dependency. Significantly, the domain of Relaxation/Reduction of Tension had the highest score among women. In patients with a greater degree of dependence, we observed a significant difference in the fields Stimulation and Automatism/Habit. The main motivational domains identified, as well as the differences found in the subanalyses, can help in building a future approach for hospitalized smokers. 
FIGURE 1. MEAN AND STANDARD DEVIATION OF THE SCORES OF THE MODIFIED SCALE OF REASONS FOR SMOKING PER GROUP OF QUESTIONS OF THE DOMAINS, IN DESCENDING ORDER. (GRAD, 2014)

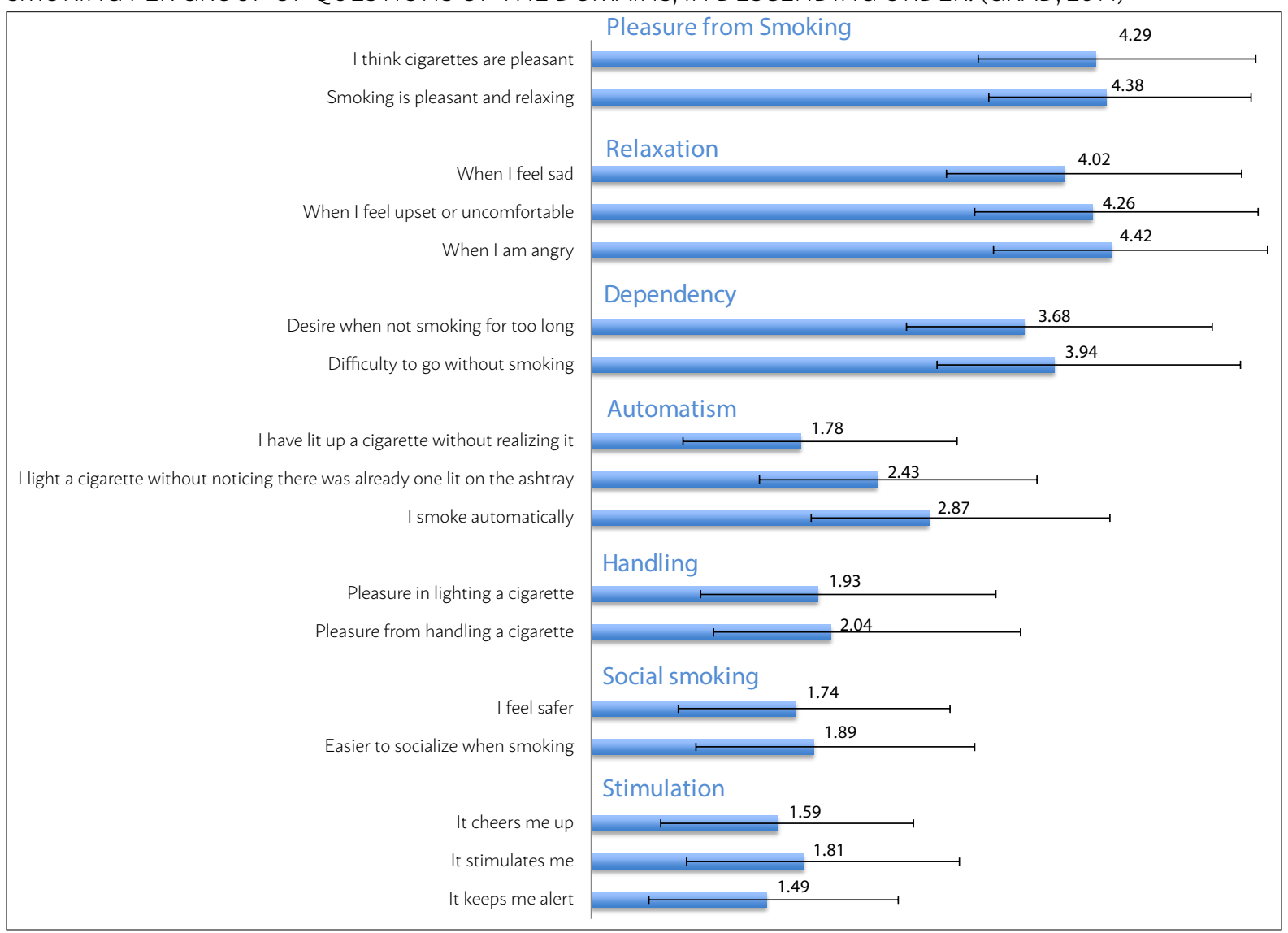

TABLE 2. MEAN SCORES FOR DOMAINS OF THE MODIFIED SCALE OF REASONS FOR SMOKING IN ALL PATIENTS HOSPITALIZED AND SEPARATED PER SEX. (GRAD, 2014)

\begin{tabular}{l|l|l|l|l} 
& \multicolumn{1}{l}{ Total } & \multicolumn{1}{l}{ Men } & \multicolumn{1}{l}{ Women } & P-value $^{*}$ \\
\hline Domains & $(n=85)$ & $(n=45)$ & $(n=40)$ & \\
\hline $\begin{array}{l}\text { Pleasure from } \\
\text { Smoking }\end{array}$ & $4.34(1.2)$ & $4.20(1.4)$ & $4.51(1.0)$ & 0.49 \\
\hline Relaxation & $4.24(1.2)$ & $3.85(1.3)$ & $4.67(0.9)$ & $<0.00$ \\
\hline Dependency & $3.80(1.4)$ & $3.63(1.4)$ & $4.01(1.3)$ & 0.24 \\
\hline Automatism & $2.36(1.1)$ & $2.44(1.2)$ & $2.28(1.0)$ & 0.74 \\
\hline Handling & $1.98(1.4)$ & $1.87(1.4)$ & $2.11(1.3)$ & 0.28 \\
\hline Social Smoking & $1.81(1.2)$ & $1.70(1.2)$ & $1.95(1.2)$ & 0.24 \\
\hline Stimulation & $1.63(1.0)$ & $1.49(0.9)$ & $1.79(1.0)$ & 0.10 \\
\hline
\end{tabular}

Results were expressed as mean and standard deviation. ${ }^{*}$ Mann-Whitney Test.

This is a study that involves a specific population, still little studied and often neglected, in a particular circumstance of hospitalization, in which the cessation of smoking is often imposed. In addition, this is an original study since there is a gap in the understanding of the main social and psychological reasons related to smoking in hospitalized patients. The standardization of instruments and the choice of validated questionnaires are fundamental points for data quality and reproducibility of studies on smoking. The ERPFM, already well-established in other countries, translated and with cultural identity, used by trained researchers to be applied in a homogeneous way, gives credibility to the results.

The findings of the current study are similar to those of Berlin et al. ${ }^{17}$, in which a population of 330 adults with a high degree of dependency had the domains of Dependency, Pleasure from Smoking, and Reduction of Tension/Relaxation with the higher scores. A survey that applied the ERPFM in adult employees of the HU-UFSC with moderate dependence showed high scores in the same domains, with a predominance of Pleasure from Smoking, which also ranked high in this sample. ${ }^{24}$

A group of growing interest in the area of smoking is composed of adolescents and young adults since they constitute a preferential target of marketing strategies of the tobacco industry. Recently, the MRSS was applied in this age group among students 
with low dependence from the Federal University of São Carlos $^{25}$ and the University of Ribeirão Preto ${ }^{26}$, both in the interior of São Paulo, with results similar to those of this study: prevalence of Pleasure from Smoking and Relaxation/Reduction of tension. It is worth noting that the people quoted in these studies were not hospitalized, despite showing high scores in similar domains.

More recently, a new scale of motivation was drawn up, with the addition of some important issues arising from an extensive inventory with 68 items (Wisconsin of reasons for smoking addiction), the MRSS. ${ }^{27}$ The so-called "Scale of Reasons for Smoking of the University of São Paulo" (ERFUSP) ${ }^{28}$ was created with the potential to become an important instrument for assessing the motivations in several clinical contexts. The scale gained 2 new domains: Weight Control and Close Association (intense emotional connection with cigarettes). The motivational profile in 311 adult smokers with a low degree of dependence showed high scores for Dependence, Pleasure from Smoking, and the Reduction of Tension/Relaxation. In 2013, a study applied this new scale to 266 adolescents and identified that the most important domains were also Pleasure from Smoking and Relaxation/ Reduction of Tension. ${ }^{29}$ Pizzichini et al. ${ }^{30}$ evaluated 183 smokers over 40 years in a population-based cross-sectional study who replied to the questionnaire of Scale of Reasons for Smoking of the University of São Paulo (ERF-USP). The main factors that lead the individual to smoke were Pleasure from Smoking and Physical Dependence. Further studies are still needed to evaluate the validity and usefulness of this scale.

It is known that men and women behave in different cultural, psychosocial and, socio-economical ways in relation to smoking., ${ }^{1,}$ In this sample of hospitalized smokers, we observed that women presented significantly higher score on the domain of Relaxation/Reduction of Tension. The study of Berlin et al. ${ }^{17}$ also points out that women generally smoke more in search of relaxation and also due to social smoking. More recently, in 2014, Pulvers et al..$^{31}$, applied the MRSS in 2376 adults smokers and found that the domain of Relaxation/Reduction of Tension had the highest score among women. These findings are relevant and in line with the results of the current study.

Comparing the MRSS domains in patients with different degrees of dependence, we found that all domains had higher scores in the group of greater dependence. However, there was a statistically significant difference in the fields Automatism/Habit and Stimulation. No strong correlation $(\mathrm{r}>0.5)$ was found between the domains and independent variables tested. However, the study by Piper et al. found a correlation between the domain of dependence and the number of cigarettes smoked per day, as well as with the Fagerström Test. ${ }^{27 .}$

One of the limitations of this study is the difficulty to generalize its findings since it involves a population with characteristics that are likely local-specific. Additionally, this study used convenience sampling, which only allows for exploratory analysis, but not probabilistic. Another criticism could be the fact that those who did not accept any approach to smoking cessation during hospitalization did not participate in the study. That group would likely be composed of a different motivational profile.

The domains mentioned are possible focus points for planning new strategies for smoking cessation involving hospitalized patients, even if they present a greater degree of dependence. Thus, during hospitalization, the Pleasure from Smoking is a factor that should be more intensely considered in order to seek new sources of satisfaction other than tobacco. In the process of cessation, stimuli to the practice of physical activity, reading, crafts, socialization, etc. must be sought individually and collectively. On the other hand, Relaxation/Reduction of Tension could involve a change in beliefs, that smoking is not relaxing, but that it reduces abstinence in dependency. In addition to the understanding of this concept, investing in teaching techniques of self-relaxation could also be a priority of the strategy directed to hospitalized smokers.

\section{CONCLUSION}

The more precise identification of factors that lead people to smoke can contribute to the development of strategies for the prevention, control, and cessation of smoking. The homogeneity of the findings in the application of motivational scales suggests that factors such as Pleasure from Smoking in general, Relaxation/Reduction of Tension especially in women, and Automatism in those more dependent should be more valued and approached on future strategies for smoking cessation of hospitalized patients. 


\section{RESUMO}

OBJETIVO: Investigar o perfil de motivações para o tabagismo entre pacientes internados em um hospital do sul do Brasil.

MÉTODOS: Estudo tipo survey que incluiu pacientes tabagistas hospitalizados. Utilizou-se a Escala de Razões para Fumar Modificada (ERPFM) e seus domínios, analisados em função do sexo e do grau de dependência.

RESULTADOS: A amostra foi composta por 85 adultos (média de 53 anos), com baixa escolaridade/renda familiar e equilibrada quanto ao sexo (masculino=52,9\%) e por especialidade clínica (48\%) ou cirúrgica (47\%). A maioria estava em estágio motivacional Ação (68\%), com carga tabágica (mediana= 39 anos/maços) e grau de dependência à nicotina elevados (56,4\%). Os domínios de maior escore da ERPFM foram: Prazer de Fumar (4,34 \pm 1,2), Relaxamento/Redução da Tensão (4,24 $\pm 1,2)$ e Dependência (3,8 $\pm 1,4)$. De forma significativa, com maior pontuação, as mulheres apresentaram o domínio Relaxamento/Redução da Tensão $(4,7 \pm 0,9)$. Naqueles com maior grau de dependência, observou-se com significância, escores mais elevados nos domínios Automatismo/Hábito e Estimulação.

CONCLUSÕES: Prazer de Fumar e Relaxamento/Redução da Tensão, especialmente em mulheres e Automatismo, naqueles mais dependentes, são fatores que devem ser mais valorizados em futuras estratégias de cessação de tabagismo em hospitalizados.

PALAVRAS-CHAVE: Tabagismo. Motivação. Pacientes internados.

\section{REFERENCES}

1. World Health Organization. WHO report on the global tobacco epidemic, 2017. Monitoring tobacco use and prevention policies. [cited 2018 March 20]. Available from: https://www.who.int/tobacco/global_report/2017/en/.

2. World Health Organization. International Agency for Research on Cancer (IARC). IARC Monographs on the Evaluation of Carcinogenic Risks to Humans: Vol 100E- Tobacco Smoking [monograph on the Internet]. Lyon: IARC; 2012. [cited 2014 Feb 26]. Available from: http://www.monographs. iarc.fr/ENG/Monographs/vol100E/mono100E-6.pdf.

3. Corrêa PC, Barreto SM, Passos VM. Smoking-attributable mortality and years of potential life lost in 16 Brazilian capitals, 2003: a prevalence-based study. BMC Public Health. 2009;9:206.

4. Levy D, Almeida LM, Szklo A. The Brazil SimSmoke policy simulation model: the effect of strong tobacco control policies on smoking prevalence and smoking-attributable deaths in a middle income nation. PLoS Med. 2012;9(11):e1001336.

5. Pinto M, Bardach A, Palacios A, Biz AN, Alcaraz A, Rodríguez B, et al. Carga de doença atribuível ao uso do tabaco no Brasil e potencial impacto do aumento de preços por meio de impostos. Documento técnico IECS N²1. Instituto de Efectividad Clínica y Sanitaria, Buenos Aires, Argentina. Maio de 2017. [cited 2018 March 20]. Available from: www.iecs.org.ar/tabaco

6. Monteiro CA, Cavalcante TM, Moura EC, Claro RM, Szwarcwald CL. Population-based evidence of a strong decline in the prevalence of smokers in Brazil (1989-2003). Bull World Health Organ. 2007;85(7):527-34.

7. Brasil. Ministério da Saúde. Secretaria de Vigilância em Saúde. Vigitel Brasil 2016: Vigilância de fatores de risco e proteção para doenças crônicas por inquérito telefônico. Brasília: Ministério da Saúde; 2016. [cited 2018 Mar 20]. Available from: http://portalarquivos.saude.gov.br/images/pdf/2017/ junho/07/vigitel_2016_jun17.pdf.

8. Gately I. La diva nicotina: the story of how tobacco seduced the world. London: Simon \& Schuster; 2001.

9. Tomkins SS. Psychological model for smoking behavior. Am J Public Health Nations Health. 1966;56(12):Suppl 56:17-20.

10. Santos SR, Gonçalves MS, Leitão Filho FS, Jardim JR. Profile of smokers seeking a smoking cessation program. J Bras Pneumol. 2008;34(9):695701.

11. Winslow E, Bohannon N, Brunton SA, Mayhew HE. Lifestyle modification: weight control, exercise, and smoking cessation. Am J Med. 1996;101(4A):4A25S-31S

12. Santos JDP, Silveira DV, Oliveira DF, Caiaffa WT. Instrumentos para avaliação do tabagismo: uma revisão sistemática. Ciênc Saúde Coletiva. 2011;16(12):4707-20.

13. Fidler JA, West R. Self-perceived smoking motives and their correlates in a general population sample. Nicotine Tob Res. 2009;11(10):1182-8.

14. Souza ES, Crippa JA, Pasian SR, Martinez JA. Modified Reasons for Smoking Scale: translation to Portuguese, cross-cultural adaptation for use in Brazil and evaluation of test-retest reliability. I Bras Pneumol. 2009;35(7):683-9.
15. Ikard FF, Tomkins S. The experience of affect as a determinant of smoking behavior: a series of validity studies. J Abnorm Psychol. 1973;81(2):172-81.

16. Russell MA. The smoking habit and its classification. Practitioner. 1974;212(1272):791-800.

17. Berlin I, Singleton EG, Pedarriosse AM, Lancrenon S, Rames A, Albin HJ, et al. The Modified Reasons for Smoking Scale: factorial structure, gender effects and relationship with nicotine dependence and smoking cessation in French smokers. Addiction. 2003;98(11):1575-83.

18. Souza ES, Crippa JA, Pasian SR, Martinez JA. Factorial structure of the Brazilian version of the Modified Reasons for Smoking Scale. Rev Assoc Med Bras (1992). 2009;55(5):557-62.

19. Rigotti NA, Clair C, Munafò MR, Stead LF. Interventions for smoking cessation in hospitalised patients. Cochrane Database of Syst Rev. 2012;(5):CD001837.

20. Barreto RB, Pincelli MP, Steinwandter R, Silva AP, Manes J, Steidle LJM, et al. Tabagismo entre pacientes internados em um hospital universitário no sul do Brasil: prevalência, grau de dependência e estágio motivacional. | Bras Pneumol. 2012;38(1):72-80.

21. Prochaska JO, DiClemente CC. Stages and processes of self-change of smoking: toward an integrative model of change. I Consult Clin Psychol. 1983;51(3):390-5.

22. Fagerström KO. Measuring degree of physical dependence to tobacco smoking with reference to individualization of treatment. Addict Behav. 1978;3(3-4):235-41.

23. Sociedade Brasileira de Pneumologia e Tisiologia; Sociedade Brasileira de Cardiologia; Associação Brasileira de Psiquiatria; Federação Brasileira das Sociedades de Ginecologia e Obstetrícia; Sociedade Brasileira de Anestesiologia; Associação Brasileira de Medicina Intensiva; Sociedade Brasileira de Cancerologia; Sociedade Brasileira de Pediatria. Tabagismo - Parte 3. Rev Assoc Med Bras. 2010;56(4):384-8

24. Alexandre M, Bruna NCD, Castagna RD, Oliveira PM, Silva RJNC, Pincelli MP, et al. Fatores associados à iniciação, adição e cessação do hábito tabágico em funcionários de um hospital universitário do sul do Brasil. J Bras Pneumol. 2011;37(supl.2R):R1-R86.

25. Rizzatti FPG, Riccetto AFM, Oliveira SB, Scarpa EC. Smoking motivation among students in Brazil: a study using the modified reasons for smoking scale. Am J Respir Crit Care Med. 2014;189(Suppl.):A1092.

26. Vargas PS, Casagrande WM, Lima MRS, Borges HSAR, Molina CB, Araújo ACS. Escalas de razões para fumar em acadêmicos do primeiro ano do curso de medicina da Universidade de Ribeirão Preto pré e pós lei antifumo em São Paulo. XXXVI Congresso Brasileiro de Pneumologia e Tisiologia (Belo Horizonte - 2012). Pôster Eletrônico número 2831.

27. Piper ME, Piasecki TM, Federman EB, Bolt DM, Smith SS, Fiore MC, et al. A multiple motives approach to tobacco dependence: the Wisconsin Inventory of Smoking Dependence Motives (WISDM-68). J Consult Clin Psychol. 2004;72(2):139-54. 
28. Souza EST, Crippa JAS, Pasian SR, Martinez JAB. Escala Razões para Fumar da Universidade de São Paulo: um novo instrumento para avaliar a motivação para fumar. J Bras Pneumol. 2010;36(6):768-78.

29. Bonilha AG, Souza ES, Sicchieri MP, Achcar JA, Crippa JA, Baddini-Martinez |. A motivational profile for smoking among adolescents. | Addict Med. 2013;7(6):439-46.

30. Pizzichini MMM, Vieira SAP, Steidle LJM, Hoepers ATC, Karloh M, Cunha
M), et al. Prevalência de tabagismo e motivações para fumar: estudo de base populacional. J Bras Pneumol. 2014;(40):69.

31. Pulvers K, Scheuermann TS, Emami AS, Basora B, Luo X, Khariwala SS, et al. Reasons for smoking among tri-ethnic daily and nondaily smokers. Nicotine Tob Res. 2014;16(12):1567-76.

32. World Health Organization. Ten facts on gender and tobacco. [cited 2018 Apr 17]. Available from: www.who.int/genter/docuents/10facts_gender_ tobacco_en.pdf. 